\title{
Health Protocol Law Enforcement
}

\author{
Sudarto $^{1}$, Megawati Barthos ${ }^{2}$ \\ \{remobjos@gmail.com ${ }^{1}$, megawati_barthos@borobudur.ac.id ${ }^{2}$ \} \\ Universitas Borobudur, Jakarta, Indonesia ${ }^{1,2}$
}

\begin{abstract}
This article analyzes the enforcement of health protocols by the police. By using the normative juridical research method, it was found that the police have a vital role in law enforcement related to health protocol violators. Enforcement of regulations associated with health protocols needs to be accompanied by good law enforcement, to suppress the spread of Covid-19 in the community. The police serve as law enforcers in ensuring the implementation of health protocols properly, as well as taking action against violators.
\end{abstract}

Keywords: Police; Law Enforcement; Health Protocol; Covid-19 pandemic

\section{Introduction}

According to the Indonesian Dictionary (KBBI), the Police are government agencies that are tasked with maintaining public security and order, while the meaning of local government rendering to the KBBI is the rulers who govern in areas such as governors and regents, demanding the Police to carry out fundamental changes in the style of policing that are spread across Indonesia and the need for cooperation with local governments in protecting the people. In each region spread throughout Indonesia, especially in several Provinces, it is led by a Regional Government Head called the Local Head. The provincial head for the Territory is known as the Lead representative, the area is named the Official, and the city is the Chairman. All of them work together for mutual progress and realize general goals for the sake of creating peace.

The development of community progress is sufficiently rapid along with the spread of the phenomenon of Human Rights (HAM), democratization, globalization, decentralization, transparency, and accountability, the traditional police style that has been carried out or carried out is then changed to a more modern and democratic and more active policing style, namely community-oriented policing or known as Community Policing. In this regard, the National Police Chief has established Community Policing as the primary and fundamental Police policy. [1]

Based on the function of the National Police, the Police are obliged to maintain security, and public order causes their performance to be in the midst of the community. The Police as part of the community and serving during the community, the success of the Police in carrying out their duties cannot be separated from the acceptance and participation of the community itself. Even more, the National Police are required to cooperate or partnership between the Police and the community, which then developed into a community policing that is has been adopted by the National Police since October 13, 2005, as a policing strategy in Indonesia. 
Everyone is obliged to act more aggressively in society so that order and security will always be maintained in society, and relations between the community and the government will be maintained as well as possible. Therefore, the law includes various regulations that determine and regulate the relationship of one person to another, namely the statutes (PP) for social life called the rule of law. Consciously or not, humans are influenced by the rules of coexistence that curb their passions and regulate the relationship between humans and one another. The living rules give a preposition of which actions can be carried out and which movements must be avoided or not carried out. The rules of life gave very clear instructions to humans on how they should behave and act in society. An identical society is often called the public as a benchmark for the progress of the nation. The public is an assembly of people who have the same interest and interest in a public issue or problem, according to Ogburn and Nimkoff, which is marked by the existence of an issue at hand. The society also has its own rules as social beings.

During the Covid-19 emergency, there are regulations related to health protocols that must be adhered to and obeyed by the community. Public visits to shopping centers during the Covid-19 pandemic increased and caused crowds at shopping centers such as malls and markets. The increase in visitors to shopping centers has also led to violations of health protocols such as not keeping a distance, washing hands, and wearing masks. Violation of the implementation of health protocols will create new clusters in the spread of Covid-19.

The government has set various provisions related to health protocols so that the spread of Covid-19 can be controlled, but the implementation is often ignored. People are often neglecting the stipulations regarding health protocols. It is a separate problem because the spread of Covid-19 will never end if health protocols do not adhere. Violation of health protocols can also endanger the health and life of a person. Law enforcement is the key to overcoming the spread of Covid-19, but if law enforcement over the implementation of health protocols is ignored, efforts to overcome Covid-19 will be in vain. Law enforcement can be influenced by several factors that cause law enforcement to not going well. Therefore, this article will review how to enforce the Covid-19 pandemic health protocol law.

\section{Method}

This research is a normative research type. The problem approach used in this study is a statutory approach and a conceptual approach to obtain accurate data, so this study uses primary and secondary data. The data and legal materials obtained through this research are then identified and collected based on the problems formulated and classified according to the sources and levels completely and comprehensively to be analyzed and discussed.

\section{Discussion}

The end of 2019 became an unexpected time, a threat to public health emerged where this outbreak was first discovered in Wuhan and named Corona Virus Disease 2019 didn't take long before a pandemic developed throughout the world so that the World Health Organization (WHO) announced Coronavirus as a pandemic on March 11, 2020. Officially in Indonesia, President Joko Widodo declared Covid-19 a non-natural national disaster on April 13, 2020, through Presidential Decree no. 12 of 2020 concerning the Determination of Non- 
Natural Disasters for the Spread of Corona Virus Disease 2019 (COVID-19) as National Disasters. [2]

The government as a policymaker has made Covid-19 a non-natural national disaster. The very fast-like spike in cases has sparked public concern, the higher the number of cases has prompted the government to immediately take steps to make anticipatory policies to deal with the coronavirus in Indonesia. The President of the Republic of Indonesia and the Regional Government and related institutions jointly make policies as a tactical step in efforts to prevent COVID-19. Starting from the central government, ministers to regional heads of provinces, districts, and even city governments.[3]

To speed up the handling of COVID-19, the government also passed the Minister of Health Regulation No. 9 of 2020 regarding the guidelines for Large-Scale Social Restrictions (PSBB) as a continuation of Government Regulation No. 21 of 2020 concerning PSBB. With the implementation of the PSBB, all office activities have been laid off. The strategy is done by the government to break the chain of distribution to certain areas, of course, by looking at the economy as the primary consideration. This policy will certainly not succeed if there is no contribution from the community, so public awareness is needed to comply with regulations so that the spread of COVID-19 can be cut off and protect people from contracting this virus. This effort is certainly done to prevent and ward off the entry and exit of the virus from one region to another.[4]

There are two references to laws that are used by the state/government to address the COVID-19 problem, and legal instruments in the health sector, namely Law no. 6 of 2018 concerning Health Quarantine and legal instruments in the field of disaster management, namely Law no. 24 of 2007 concerning Disaster Management. Its derivative health sector is in the form of PSBB, its derivative disaster sector is in the form of a Task Force.

The health protocol is based on the Guideline of the Minister of Health of the Republic of Indonesia Number 9 of 2020 concerning Rules for Huge Scope Social Limitations With regards to Speeding up the Treatment of Coronavirus. Article 13 paragraph (8) Permenkes No. 9 of 2020 then mandates the establishment of a health protocol. The Ministry of Health then issued a Decree of the Minister of Health of the Republic of Indonesia Number HK.01.07/Menkes/382/2020 concerning Health Protocols for the Community in Public Places and Facilities in the Context of Prevention and Control of Corona Virus Disease 2019 (Kepmenkes 382/2020). Health protocols arise because of an effort to overcome disease outbreaks that occurred in Indonesia. The health protocol is a step taken after the implementation of Large-Scale Social Restrictions (PSBB) rules in some parts of Indonesia as stated in Article 59 of Law 6 of 2018 concerning Health Quarantine (Law No. 6 of 2018). PSBB was then regulated in Government Regulation No. 21 of 2020 regarding PSBB in the context of Accelerating the Handling of the Covid-19 Virus (PP No. 21 of 2020). Article 5 PP No. 21 of 2020 states that if PSBB has been stipulated by the Minister of Health, the regional government is obliged to implement and pay attention to the provisions as stipulated in Law No. 6 of 2018. It means that in implementing PSBB, prohibition rules or criminal stipulations governing health quarantine are also applicable.[5]

Article 93 of Law No. 6 of 2018 states that anyone who hinders the implementation of health quarantine that caused a public health emergency can be sentenced to a maximum imprisonment of 1 (one) year and/or a maximum fine of Rp. 100,000,000 (one hundred million rupiahs). Based on this, it can be said that people who intentionally do not comply with the rules regarding health protocols can be given criminal sanctions as referred to in Article 93 of Law no. 6 of 2018. As a form of the government's seriousness in tackling Covid19, the President then issued Presidential Instruction No. 6 of 2020 concerning Improvement 
of Discipline and Law Enforcement of Health Protocols in the Prevention and Control of Corona Virus Disease 2019.[6]

Sanction rules for violating health protocols already exist, but in daily implementation, violations of health protocols still occur in various places, especially in the market. Law enforcement has not run optimally is because there are still many people who are not aware of the importance of implementing health protocols. H.C. Kelman stated that someone's obedience is compliance was someone obeys a rule only because he is afraid of being sanctioned. Based on H.C. Kelman, it can be said that the public's legal awareness to implement health protocols is still limited to compliance. The public will obey the rules when meeting with the police, Satpol PP, or other Covid-19 Task Forces. However, if they do not meet with law enforcement, people will tend to ignore the rules of health protocols. [7]

According to Soerjono Soekanto, law enforcement can be affected by a few variables, to be specific legitimate elements, law implementation, offices or offices, society, and culture. Legal elements, namely laws and regulations governing health protocols such as Law no. 6 of 2018, Presidential Instruction No. 6 of 2020, as well as governor/mayor/regent regulations regarding PSBB.[2] The set of rules for implementing law enforcement on the implementation of health protocols already exists, but it is not yet optimal. The existing sanctions cannot provide a deterrent effect to violators of the health protocol rules.

Law enforcement factors, namely law enforcement apparatus, namely the police and Satpol PP. One of the instructions given in Presidential Instruction No. 6 of 2020 to the Chief of the Indonesian National Police, namely to streamline law enforcement against violations of health protocols. In addition, to enforce regional regulations, regional apparatus such as the Satpol PP are tasked with implementing health protocol rules. Law enforcement on the implementation of health protocols can currently be said to be declining. The Ministry of Home Affairs said several reasons for the decline in health protocol discipline, namely the saturation of the community and officers and the relaxation of health protocols.

Community factors, namely factors that have a strong influence on the implementation of law enforcement. This factor is necessary because the higher the public awareness of the laws and regulations, the better law enforcement will be achieved. The application of health protocols is related to community legal compliance.[8] People nowadays often ignore health protocols, such as not wearing a mask or wearing a mask but not covering the nose and mouth. Another violation is not keeping the distance between each other.

Another factor is the cultural factor. Cultural factors are crucial to be implemented because culture serves as a guide for people to act, commit, and determine their attitudes. It needs to build a culture of obeying laws and regulations to make people understand that rules are formed for them to feel safe and comfortable. The culture of enforcing health protocol rules by the community means that the community participates in preventing the spread of Covid-19.

Law Enforcement Against health protocol violations during the Coronavirus pandemic is done dependent on legal guidelines, by executing Local area Movement Limitations (PKM), Huge Scope Social Limitations (PSBB) as a type of law requirement against wellbeing convention infringement during the Coronavirus pandemic through socialization-socialization in forestalling the spread of the Coronavirus infection and Enormous Scope Social Limitations (PSBB) by forcing sanctions on violators.[9] Nonetheless, law requirement against wellbeing convention infringement has not been carried out effectively. It is because of the event of the carelessness of wellbeing conventions did by the local area.

Many sanctions are included in each policy aimed at violators to feel the deterrent effect of their actions. In general, sanctions in-laws and regulations, including administrative sanctions, are usually associated with/or a consequence of a norm formulated in the form of a 
prohibition, command (must), or obligation (obligation). A norm that contains a prohibition, command (must), or obligation will have difficulty in enforcement if it is not accompanied by sanctions.

The application of sanctions for the negligence of health protocols during the COVID-19 pandemic is regulated in the Regional Government Regulation concerning PSBB by applying written warnings, managerial approvals, social assents, and criminal authorizations to violators. Notwithstanding, the use of assents against violators has not given an obstacle impact to wellbeing convention violators. Regarding the implementation of law enforcement, health protocols have been carried out following applicable regulations, and cooperation between agencies can run well. And the government, through the task force, carries out judicial operations involving the Civil Service Unit, the Transportation Service in collaboration with the Indonesia National Army, and the Police.

\section{Conclusion}

Law enforcement of health protocols in Indonesia can be said to have not been going well. It is because there are still many violations of health protocols, such as in shopping centers. Several factors cause law enforcement to not be well-operating, namely related to statutory factors, law requirement elements, offices or offices factors, local area factors, and social variables. For this reason, the synergy between agencies, both from the government and law enforcement officials, is needed to increase their role by actively monitoring to ensure that health protocols are especially well performed.

\section{Referensi}

[1] H. Djanggih, "THE EFFECTEVENES OF INDONESIAN NATIONAL POLICE FUNCTION ON BANGGAI REGENCY POLICE INVESTIGATION (Investigation Case Study Year 2008-2016)," J. Din. Huk., vol. 17, no. 2, p. 153, 2017.

[2] R. A. M. dan R. N. Nurwati, " The impact of the COVID-19 pandemic on the increase in the unemployment rate in Indonesia," Kesejaht. Sos., 2020.

[3] Z. Zahrotunnimah, " Regional Government Tactical Steps in Preventing the Spread of the Corona Covid-19 Virus in Indonesia," SALAM J. Sos. dan Budaya Syar-i, vol. 7, no. 3, pp. 247-260, Mar. 2020, doi: 10.15408/sjsbs.v7i3.15103.

[4] I. L. Made, " Significance of the Influence of Sentiment for the Implementation of PSBB on the Economic Aspect: Effect on the Rupiah Exchange Rate and Stock Return (Case Study of the Covid-19 Pandemic)," J. Bina Akunt., vol. 7, no. 2, pp. 223-239, Aug. 2020, doi: 10.52859/jba.v7i2.98.

[5] P. S. Saraswati, " Legal Policy Against the Handling of the Covid-19 Pandemic in Indonesia,” KERTHA WICAKSANA, vol. 14, no. 2, pp. 147-152, Jul. 2020, doi: 10.22225/kw.14.2.1923.147-152.

[6] D. S. P. Astuti, “Economy during the Covid-19 Pandemic,” Suara Merdeka, 2020.

[7] D. Telaumbauna, " Juridical Review of Determination of Public Health Emergency Due to Covid-19," J. Educ. Dev., 2020.

[8] K. R. Ayu Kurniawati, F. H. Santosa, and S. Bahri, " Socialization of Healthy Living Amid the Corona Virus Outbreak," JPMB J. Pemberdaya. Masy. Berkarakter, vol. 3, no. 1, pp. 58-65, May 2020, doi: 10.36765/jpmb.v3i1.225. 
[9] F. P. Disantara, "State Responsibilities During the Covid-19 Pandemic," JCH (Jurnal Cendekia Hukum), vol. 6, no. 1, p. 48, 2020, doi: 10.33760/jch.v6i1.262. 